\title{
Characterization of phytochemicals and yield components in various okra (Abelmoschus esculentus) genotypes
}

\author{
MUHARAMA YORA ${ }^{1}$, MUHAMAD SYUKUR ${ }^{2, \boldsymbol{\varphi}}$, SOBIR $^{2}$ \\ ${ }^{1}$ Plant Breeding and Biotechnology Graduate Program, Department of Agronomy and Horticulture, Faculty of Agriculture, Institut Pertanian Bogor. \\ Jl. Raya Dramaga, Bogor 16680, West Java, Indonesia. email: muharamayora27@gmail.com. \\ ${ }^{2}$ Department of Agronomy and Horticulture, Faculty of Agriculture, Institut Pertanian Bogor. J1. Raya Dramaga, Bogor 16680, West Java, Indonesia. \\ "email: muhsyukur@yahoo.com.
}

Manuscript received: 23 September 2018. Revision accepted: 17 November 2018

\begin{abstract}
Yora M, Syukur M, Sobir. 2018. Characterization of phytochemicals and yield components in various okra (Abelmoschus esculentus) genotypes. Biodiversitas 19: 2323-2328. Okra is a group of vegetable and medicinal plants possessing various health benefits. This plant has different shapes, colors and nutritional content. In Indonesia, this plant has not been widely cultivated, because the socialization and information of okra benefits to the Indonesian people are still limited. The aims of this study were to analyze phytochemicals, anthocyanins and carotene content, and to analyze the correlation among okra genotypes based on their morphological characters. This study was conducted from September 2017 to January 2018, using Complete Randomized Group Design with three replications and 13 genotypes namely PB01Nai, PB02Zah, PB03Clem, PB04Stri, PB13-293, PB05-291, PB06-004, PB07-127, PB08P1, PB09P2, PB10-MC, PB11-069, and PB12-OR. The observation was made on the variables of phythochemical, anthocyanin, carotene, chlorophyll and yield components on okra fruit. The results showed that all okra fruits have steroid phytochemical content and some of them had phytochemical content of Saponin and Tanin. Based on the carotene and chlorophyll analysis of 13 okra fruit genotypes, it showed that PB11-069 genotype contained the highest carotene and chlorophyll contents. While okra fruit having the highest anthocyanin content was PB05-291. The results of cluster analysis showed that okra was clustered into three color groups. The anthocyanin content found in okra fruit does not correlated with the yield component variable. Chlorophyll- $\alpha, \beta$, and total chlorophyll are positively correlated to carotene in okra fruit and variable number of fruits. The character of number and weight per plant greatly influences the determination of the selection process. Accordingly, the characters can be used as a selection character so as to produce a high yield okra containing high chlorophyll and carotene contents.
\end{abstract}

Keywords: Antocyanin, caroten, chloropyhll, phytochemicals, yield components

\section{INTRODUCTION}

Okra includes a group of vegetable and medicinal plants that have good nutrition for health. This is supported by the results of plant work (2010) which showed that okra is one of 940 plant species in Indonesia which is efficacious as a medicinal plant (Nugroho, 2010; Prakoso et al. 2016). However, this development is sluggish in Indonesia, because the socialization and information about the benefits of okra to the Indonesian people are limited.

Based on the color of the fruit, okra is divided into green and red which has a variety of nutrients and minerals. Okra fruit contains vitamins, calcium, and potassium IBPGR (1991). Okra also contains other nutrients, namely protein $2.0 \mathrm{~g} ; 0.1 \mathrm{~g}$ fat; $7.6 \mathrm{~g}$ carbohydrates and $33 \mathrm{kcal}$ per $100 \mathrm{~g}$. Okra fruit can reduce serum cholesterol, which can reduce heart disease or cardiovascular problems (Sindhu et al. 2016). In Ethopia, okra fruit is used to eliminate blood sugar levels for diabetics (Gemede et al. 2015), that is obtained from special fiber content (Kumar et al. 2013). Okra fruit also contains protein and oil riching in linoleic acid, unsaturated fatty acids and coffee extract free from dried seeds (Gemede et al. 2015).

Increased production of okra plants can be influenced by flowering age, plant age, fruit diameter, fruit length, fruit weight and internode distance. The Laboratory of Genetics and Plant Breeding, Department of Agronomy and Horticulture, IPB has a total of 13 okra genotypes. This collection is used to study its genetic diversity which is evaluated based on morphology, phytochemical, anthocyanin, carotene, chlorophyll and its production.

Correlations between real characters play an important role for quantitative character selection because the description of genetic abilities is difficult, because of the influence of the environment. A close relationship between the desired characters and unattended characters can increase the work effectiveness of breeders in the selection process (Falconer and Mackay 1996). This study aimed to know phytochemicals and antioxidants contents in okra fruit, to cluster 13 okra genotypes and to analyze the correlation between the characters of the yield components, anthocyanin, carotene, and chlorophyll so that some of these characters become special identifiers of a genotype.

\section{MATERIALS AND METHODS}

\section{Study area and genetic material}

This research was conducted at the Bogor Agricultural University Experimental Garden, Dramaga Subdistrict, 
Bogor, West Java, Indonesia in October 2017 until January 2018. Analysis of chlorophyll, carotene and anthocyanin were carried out in the Postharvest Laboratory of the Department of Agronomy and Horticulture, Bogor Agricultural University, West Java, Indonesia. Phytochemical analysis was carried out at the Laboratory of the Biopharmaca Study Center, Bogor Agricultural University, Indonesia. The genetic material used in this study consisted of 13 okra genotypes namely PB01Nai, PB02Zah, PB03Clem, PB04Stri, PB13-293, PB05-291, PB06-004, PB07-127, PB08P1, PB09P2, PB10-MC, PB11-069, PB12 -OR. This genetic material is a collection of Genetics and Plant Breeding Laboratories, Department of Agronomy and Horticulture, Faculty of Agriculture, Bogor Agricultural University. The design used was a complete randomized group design (RKLT) with three replications with a plot area of $5 \mathrm{~m} \mathrm{x} 1 \mathrm{~m}$.

\section{Procedures}

\section{Morphological characterization}

The seedlings with 2-3 perfect leaves were planted after \pm 14 days of sowing. Plants were watered every day in the afternoon as maintenance. The plants were fertilized with NPK solution (16: 16: 16) $10 \mathrm{~g} \mathrm{1-1}$ once a week, in which $250 \mathrm{ml}$ of fertilizer solution was applied in each plants. The plants were then sprayed with fungicides with active ingredients mancozeb $80 \%$ or propineb and prefenophos active insecticides. The weed growing around the plants was manually removed. The plant harvesting was done in the $6^{\text {th }}$ week after planting, and carried out once every two days within a month. Okra fruit was ready to be harvested after the fruit size was $10-12 \mathrm{~cm}$ long or 5-10 days after flowering time.

Observations were made on qualitative and quantitative characters, including plant growth habitus variables, branching forms, stem color, stem color intensity, leaf shape, leaf color, petiole color, flower crown color, young fruit color, shape of fruit surface, number of locules on fruit, fruit tip shape, fruit base shape, seed shape, seed color, fruit weight per plant, number of fruit, fruit weight, internode distance, fruit length, fruit diameter. Observations on these variables refer to the International Union for The Protection of New Varieties of Plant testing guide (UPOV 1999) and the National Bureau of Plant Genetic Resources (NBPGR 2000).

\section{Phytochemicals}

Okra fruits with the size of $10-12 \mathrm{~cm}$ long or at the age of 5-10 days after flowering time were prepared by cleaning okra, which were then cut thin and dried under the sun for about 5 days until the moisture content was $<10 \%$. The fried okra was ground until it obtained 100 mesh of powder. The okra powder was weighed as much as $100 \mathrm{~g}$, which was then extracted by maceration method according to the method approached by Nurcholis et al. (2015), using $70 \%$ ethanol solvent at a ratio of 1: 10 for 48 hours. Every 1 x 24 hours the filtrate was taken by filtering, then extraction was continued $1 \times 24$ hours according to the previous stages. The collected filtrate was then evaporated with a vacuum evaporator (evaporator) to obtain a thick extract at a temperature of $\pm 50^{\circ} \mathrm{C}$. Extraction was done in a simple way without repetition.

The extract results were analyzed qualitatively by phytochemical content based on standard methods according to Harborne (1998) to determine the presence of secondary metabolite compounds, i.e., tannin, saponins, terpenoids, and steroids. The addition of $1 \% \mathrm{FeCl}_{3}$ in the extract resulting in a dark blue color indicated the presence of tannin compounds. The sample contained saponin compounds if the presence of foam was shown during the dissolution sample with distilled water followed by heating and shaking process. The sample extract with Lieberman Burchard reagent giving a red/blue color indicated the presence of terpenoids, while if the color blue/green showed the presence of steroids.

\section{Chlorophyll, carotene, and anthocyanin analysis}

Fresh okra fruit was cut and weighed about 100-200 mg. Each piece of okra fruit was then put into a tube and stored in the freezer for $1 \times 24$ hours. Each step and analysis process of chlorophyll, carotene and anthocyanin were analyzed according to the procedure developed by Lichtenthaler (1987) and Sims et al. (2002).

\section{Data analysis}

Data analysis was performed using ANOVA, cluster analysis, and correlation analysis. Phenotypic correlation coefficients were calculated by standard procedures (Johnson et al. 1955). The analysis was carried out using PB-STAT software, and STAR. Analysis of anthocyanin, carotene, chlorophyll and phytochemistry was carried out by analyzing the results of extraction of young okra fruit using spectrophotometry and HPLC so that the quantitative data of phytochemical content of okra, i.e., anthocyanin, betacarotene, chlorophyll and the qualitative content of the phytochemical content of okra were obtained.

\section{RESULTS AND DISCUSSION}

Okra belongs to a group of vegetable and medicine plant which have a high benefits for the body. The phytochemical contents of okra fruit are crucial to be elucidated in order to support okra benefits. Phytochemical (qualitative) content of fruit extracts of 13 okra genotypes was presented in Table 1. All okra fruits have steroid secondary metabolites. All types of steroids and their metabolites had an important role in medical science, biochemical and physiological. In medical science, synthetic steroids are used for antibiotics, osteoporosis medicine, and anesthesia (Sultan et al. 2015). The result showed that saponin was found in PBNai, PB04Stri, PB13293, PB07-127, PB11-069, PB09P2, and PB08P1. Barky et al. (2017) explained that saponin can be used to reduce blood glucose levels, which was efficient in the remediation of diabetes mellitus. In addition, Marrelli et al. (2016) also described the important role of saponins pharmacological compounds as antifungal, insecticidal, anthelmintic, cytotoxic, anti-inflammatory, immunostimulant, hypocholesterolemic and hypoglycemic. 
Secondary tannin metabolites were found in the PB02Zah, PB05-291, PB13-293 and PB11-069 genotypes. Tannins contained in the plant tissues both in the leaves and fruit could be used to relieve throat disease, diarrhea, dysentery. It could also cause regression of the tumors if it was consumed in the long term so that the tumor contained in the body tissues could be healed (Ashok et al. 2012). Tannin in the medical sciences compound acts as an antidiarrheal, hemostatic, and anti-hemorrhoidal. Antiinflammatory effects contained in the tannin can help to control several disease indications such as gastritis, esophagitis, enteritis, and chronic intestinal disorders (Ashok et al. 2012). Tannins play a role in decreasing blood glucose levels because tannins are astringent, which works to preserve intestinal mucous membrane proteins and form a layer that protects the intestines, which inhibits blood glucose uptake (Rotblatt et al. 2002). However, quinon and triterpenoid secondary metabolites were not identified in okra fruit.

Another secondary metabolites, carotene can be obtained from vegetables possessing a dark green and yellow color (Khoo et al. 2011). The amount of anthocyanin, carotene, and chlorophyll contained in okra fruit was presented in Table 2. PB11-069 genotype had the amount of chlorophyll- $\alpha$ of $0.102 \mathrm{mg} / 100 \mathrm{~g}$, while chlorophyll- $\beta$ was $0.041 \mathrm{mg} / 100 \mathrm{~g}$, and total chlorophyll was $0.143 \mathrm{mg} / 100 \mathrm{~g}$ and also the highest carotene content $(0.0342 \mathrm{mg} / 100 \mathrm{~g})$ of all used genotypes sample. The density of green in the fruit will affect the increased amount of carotene and chlorophyll in the fruit. Khoo et al. (2011) explained that there is a bond between carotenoids and chlorophyll which affects the color produced in the fruit. Khoo et al. (2011) also reported that the carotenoids in okra consisting of alpha-carotene $(0.028 \mathrm{mg} / 100 \mathrm{~g})$ and beta-carotene $(0.43 \mathrm{mg} / 100 \mathrm{~g})$. In addition, Block (1994) reported that the number of carotenoids obtained from okra ranged around $\pm 0.1 \%$. Carotenoids and chlorophyll also play an important role in the prevention of various diseases such as cancer, cardiovascular disease and several other chronic diseases (Znidarcic et al. 2011). Chlorophyll is a green pigment containing plant cell chloroplasts. Chlorophyll pigments are not only very useful in photosynthesis, but also beneficial to human health. Chlorophyll has therapeutic properties which are useful for stimulating the immune system, preventing cancer and often used in cancer chemotherapy, normalized blood pressure, and preventing anemia (Inanc 2011).

Table 1. Analysis of phytochemical content on fruit characters 13 okra genotypes

\begin{tabular}{|c|c|c|c|c|c|}
\hline \multirow{2}{*}{ Genotypes } & \multicolumn{5}{|c|}{ Phytochemical } \\
\hline & Tannin & Saponins & Quinon & Steroid & Triterpenoid \\
\hline PB01Nai & - & + & - & + & - \\
\hline PB02Zah & + & - & - & + & - \\
\hline PB12-OR & - & - & - & + & - \\
\hline PB04Stri & - & + & - & + & - \\
\hline PB05-291 & + & - & - & + & - \\
\hline PB13-293 & + & + & - & + & - \\
\hline PB06-004 & - & - & - & + & - \\
\hline PB07-127 & - & + & - & + & - \\
\hline PB10-MC & - & - & - & + & - \\
\hline PB11-069 & + & + & - & + & - \\
\hline PB03Clem & - & - & - & + & - \\
\hline PB09P2 & - & + & - & + & - \\
\hline PB08P1 & - & + & - & + & - \\
\hline
\end{tabular}

Note : $+=$ presence; $-=$ absence

Table 2. Middle value 13 anthocyanin, carotene and chlorophyll content in okra fruit

\begin{tabular}{|c|c|c|c|c|c|}
\hline Genotypes & Chlorophyll-a & Chlorophyll- $\beta$ & Total chlorophyll & Carotene & Anthocyanin \\
\hline PB01Nai & $0.049^{\text {ef }}$ & $0.018^{\text {ef }}$ & $0.067^{\text {ef }}$ & $0.017^{\mathrm{ef}}$ & $0.004^{\mathrm{d}}$ \\
\hline PB02Zah & $0.055^{\text {def }}$ & $0.022^{\text {def }}$ & $0.077^{\text {def }}$ & $0.019^{\text {def }}$ & $0.008^{\mathrm{abc}}$ \\
\hline PB12-OR & $0.045^{\mathrm{f}}$ & $0.018^{\mathrm{ef}}$ & $0.063^{\text {ef }}$ & $0.017^{\text {ef }}$ & $0.005^{\mathrm{bcd}}$ \\
\hline PB04Stri & $0.078^{\mathrm{bc}}$ & $0.030^{\mathrm{bcd}}$ & $0.109^{b c}$ & $0.026^{b c}$ & $0.006^{\mathrm{abcd}}$ \\
\hline PB05-291 & $0.0367^{\mathrm{f}}$ & $0.014^{\mathrm{f}}$ & $0.051^{\mathrm{f}}$ & $0.014^{\mathrm{f}}$ & $0.009^{\mathrm{a}}$ \\
\hline PB13-293 & $0.964^{\mathrm{ab}}$ & $0.033^{\mathrm{ab}}$ & $0.133^{\mathrm{ab}}$ & $0.031^{\mathrm{ab}}$ & $0.005^{\text {cd }}$ \\
\hline PB06-004 & $0.038^{f}$ & $0.015^{f}$ & $0.052^{\mathrm{f}}$ & $0.012^{\mathrm{f}}$ & $0.007^{\mathrm{abcd}}$ \\
\hline PB07-127 & $0.036^{\mathrm{f}}$ & $0.015^{\mathrm{f}}$ & $0.051^{\mathrm{f}}$ & $0.013^{\mathrm{f}}$ & $0.008^{\mathrm{ab}}$ \\
\hline PB10-MC & $0.038^{\mathrm{f}}$ & $0.014^{\mathrm{f}}$ & $0.052^{\mathrm{f}}$ & $0.013^{\mathrm{f}}$ & $0.007^{\mathrm{abcd}}$ \\
\hline PB11-069 & $0.102^{\mathrm{a}}$ & $0.041^{\mathrm{a}}$ & $0.143^{\mathrm{a}}$ & $0.0342^{\mathrm{a}}$ & $0.007^{\mathrm{abcd}}$ \\
\hline PB03Clem & $0.084^{\mathrm{abc}}$ & $0.033^{\mathrm{bc}}$ & $0.117^{\mathrm{abc}}$ & $0.027^{\mathrm{bc}}$ & $0.006^{\mathrm{abcd}}$ \\
\hline PB09P2 & $0.068^{\text {cde }}$ & $0.026^{\text {cde }}$ & $0.094^{\text {cde }}$ & $0.022^{\text {cde }}$ & $0.007^{\text {abcd }}$ \\
\hline PB08P1 & $0.075^{\mathrm{bcd}}$ & $0.029^{\mathrm{bcd}}$ & $0.104^{\text {bcd }}$ & $0.025^{\mathrm{bcd}}$ & $0.006^{\mathrm{abcd}}$ \\
\hline
\end{tabular}

Note : Numbers followed by the same letter in the same column were not significantly different according DMRT of 5\%. 
Table 2 shows all okra fruits have anthocyanin. However, the amount of anthocyanin content between genotypes is almost the same except for the PB01Nai genotype $(0.004 \mathrm{mg} / 100 \mathrm{~g})$. The density of red in the fruit could be observed in the amount of obtained anthocyanin . Anthocyanins contained in fruits and vegetables are beneficial as an antioxidant, cancer, and degenerative diseases. It also reduce levels of sugar known as antidiabetic fruit (Alsuhaibani et al. 2017). In addition, anthocyanins also affect blood vessels and platelets, which could reduce the risk of coronary heart disease (Mazza 2007).

Other important information that can be used as an added value of a genotype is the character of the okra plant components. The middle values of each genotype based on fruit weight character per plant, fruit weight, number of fruit, fruit diameter, fruit length and internode distance were described in Table 3. This table explains that the highest middle value in fruit weight character per plant $(619.88 \mathrm{~g})$ and number of fruit (42.33) was obtained in the PB13-293 genotype. PB03Clem genotype had the highest middle value based on fruit weight character. The highest middle value for the character of fruit diameter, fruit length and internode distance was found in PB08P1 $(1.89 \mathrm{~cm})$, PB12-OR $(12.73 \mathrm{~cm})$, and PB10-MC $(9.74 \mathrm{~cm})$ genotypes. This explains that the high fruit weight per plant is not always influenced by fruit weight, fruit diameter and fruit length. Fruit weight per plant could also be high, if the number of fruits was high, but has a short internode distance.

Information on the relationship between genotypes is also needed to see the diversity and correlation between genotypes. It could be observed on dendogram in Figure 1 and PAM Cluster Plot in Figure 2. Based on dendogram and PAM Cluster Plot analysis, it showed that the grouping of 13 okra genotypes was divided into three main groups. The division of this group divides on a scale of \pm 0.36 .

Group I consisted of green genotypes, i.e PB01Nai, PB08P1, PB04Stri, PB12-OR, and PB03Clem. Group II consisted of red genotypes was PB10-MC, PB07-127, PB05-291, PB06-004, PB02Zah, and PB09P2 Ungu. Group
III consisted of dark green genotypes was PB13-293 and PB11-069. Genotype grouping based on PAM Cluster Plot showed that the diversity of each genotype reached $54.74 \%$.

Based on the results of Pearson correlation analysis of the 13 genotypes presented in Table 4, it was explained is the fruit weight per plant was positively correlated and very significantly different from the number of fruits, chlorophyll- $\alpha$, chlorophyll- $\beta$, and total chlorophyll. Fruit weight per plant has a negative correlation and significantly different from internode distance. Kumar et al. (2016) reported is fruit weight per plant on okra had a positive correlation and significantly different with the number of fruit per plant, and the fruit consumption weight per plant had a negative correlation and significantly different from the internode distance.

The positive correlation highly significant and also occur between the characters number of fruits with chlorophyll- $\alpha$ and chlorophyll- $\beta$, but a negative correlation highly significant and occurs between the character spacing amount of fruit with Internode. The character of fruit diameter has a negative correlation and very significantly with the character length of the fruit and internode distance. This explained is the character of the diameter of the fruit has a close relationship that is opposite to the long character of the fruit.

The character of internode distance is negatively correlated and very different from chlorophyll- $\alpha$, chlorophyll- $\beta$, and total chlorophyll. This shows that the character of the internode distance with chlorophyll- $\alpha$, chlorophyll- $\beta$, and total chlorophyll also has an opposite close relationship. Furthermore, positive and very different correlations were seen in the character of chlorophyll- $\alpha$ with chlorophyll- $\beta$ and total chlorophyll. This shows that increased chlorophyll- $\alpha$ also affects the amount of chlorophyll- $\beta$ and total chlorophyll. A positive and very different correlation was also seen between chlorophyll- $\beta$ with total chlorophyll and carotene and between total chlorophyll and carotene. This shows that increased chlorophyll- $\beta$ and total chlorophyll will be followed by an increased in the amount of carotene obtained.

Table 3. Middle value of 13 genotypes based on yield components in okra fruits

\begin{tabular}{|c|c|c|c|c|c|c|}
\hline Genotypes & $\begin{array}{c}\text { BBTT } \\
\text { (g) }\end{array}$ & $\begin{array}{c}\text { BBT } \\
\text { (g) }\end{array}$ & JB & $\begin{array}{r}\text { DMB } \\
(\mathbf{c m})\end{array}$ & $\begin{array}{c}\text { PJGB } \\
\text { (cm) }\end{array}$ & $\begin{array}{r}\text { JRKI } \\
(\mathrm{cm})\end{array}$ \\
\hline PB01Nai & $447.06^{\mathrm{bcd}}$ & $14.35^{\mathrm{abc}}$ & $31.00^{\mathrm{bcd}}$ & $1.61^{\mathrm{d}}$ & $11.47^{\mathrm{bcd}}$ & $6.30^{\mathrm{cd}}$ \\
\hline PB02Zah & $495.57^{\mathrm{ab}}$ & $13.37^{\mathrm{bc}}$ & $37.00^{\mathrm{abc}}$ & $1.61^{\mathrm{d}}$ & $10.63^{\mathrm{def}}$ & $5.78^{\mathrm{d}}$ \\
\hline PB12-OR & $227.97^{\mathrm{e}}$ & $14.84^{\mathrm{abc}}$ & $15.33^{\mathrm{e}}$ & $1.50^{\mathrm{e}}$ & $12.73^{\mathrm{a}}$ & $7.66^{\mathrm{b}}$ \\
\hline PB04Stri & $407.18^{\mathrm{bcd}}$ & $12.95^{\mathrm{c}}$ & $31.33^{\mathrm{bcd}}$ & $1.60^{\text {de }}$ & $11.75^{\mathrm{bc}}$ & $6.69^{c}$ \\
\hline PB05-291 & $443.53^{\mathrm{bcd}}$ & $15.21^{\mathrm{abc}}$ & $29.00^{\mathrm{cd}}$ & $1.71^{\mathrm{c}}$ & $11.31^{\mathrm{cd}}$ & $6.38^{\mathrm{cd}}$ \\
\hline PB13-293 & $619.88^{a}$ & $14.68^{\mathrm{abc}}$ & $42.33^{\mathrm{a}}$ & $1.82^{\mathrm{ab}}$ & $10.37^{\mathrm{ef}}$ & $4.19^{\mathrm{e}}$ \\
\hline PB07-127 & $342.72^{\text {cde }}$ & $13.51^{\mathrm{bc}}$ & $25.67^{d}$ & $1.77^{\mathrm{bc}}$ & $11.00^{\text {cde }}$ & $6.22^{\mathrm{cd}}$ \\
\hline PB10-MC & $338.13^{\mathrm{de}}$ & $13.02^{\mathrm{c}}$ & $26.00^{\mathrm{d}}$ & $1.59^{\mathrm{de}}$ & $11.51^{\mathrm{bcd}}$ & $9.74^{\mathrm{a}}$ \\
\hline PB11-069 & $489.64^{\mathrm{abc}}$ & $14.39^{\mathrm{abc}}$ & $34.33^{\mathrm{abcd}}$ & $1.82^{\mathrm{ab}}$ & $9.81^{\mathrm{f}}$ & $4.00^{\mathrm{e}}$ \\
\hline PB03Clem & $515.69^{\mathrm{ab}}$ & $16.50^{\mathrm{a}}$ & $31.33^{\mathrm{bcd}}$ & $1.83^{\mathrm{ab}}$ & $10.74^{\mathrm{de}}$ & $6.30^{\mathrm{cd}}$ \\
\hline PB09P2 & $520.00^{\mathrm{ab}}$ & $13.33^{\mathrm{c}}$ & $39.00^{\mathrm{ab}}$ & $1.57^{\mathrm{de}}$ & $12.23^{\mathrm{ab}}$ & $6.42^{\mathrm{cd}}$ \\
\hline PB08P1 & $406.48^{\mathrm{bcd}}$ & $13.52^{b c}$ & $30.00^{\text {bcd }}$ & $1.89^{\mathrm{a}}$ & $7.80^{\mathrm{g}}$ & $5.76^{\mathrm{d}}$ \\
\hline
\end{tabular}

Note: Numbers followed by the same letter in the same column were not significantly different according DMRT, $5 \%$ level, BBT $=$ fruit weight per plant, $\mathrm{JB}=$ number of fruit, $\mathrm{DMB}=$ fruit diameter, $\mathrm{PJB}=$ length of fruit, $\mathrm{JRKI}=$ internode distance 
Table 4. Correlation analysis of yield components characters and chlorophyll, carotene and anthocyanins for 13 genotypes of okra

\begin{tabular}{|c|c|c|c|c|c|c|c|c|c|c|}
\hline Character & BBT & $\mathbf{J B}$ & DMB & PJGB & JRKI & Kloro A & Kloro B & Ttlkloro & Caroten & Anto \\
\hline BBTT & 0.157 & $0.941^{* *}$ & 0.422 & -0.323 & $-0.653^{* *}$ & $0.703^{* *}$ & $0.618^{* *}$ & $0.665^{* *}$ & 0.477 & -0.145 \\
\hline BBT & 1.00 & -0.181 & 0.377 & 0.009 & -0.269 & -0.006 & 0.007 & 0.079 & 0.040 & -0.195 \\
\hline $\mathrm{JB}$ & & 1.00 & 0.286 & -0.317 & $-0.571^{* *}$ & $0.686^{* *}$ & $0.599^{* *}$ & $0.618^{* *}$ & 0.441 & -0.057 \\
\hline DMB & & & 1.00 & $-0.831^{* *}$ & $-0.617^{* *}$ & 0.494 & 0.335 & 0.454 & 0.340 & 0.456 \\
\hline PJGB & & & & 1.00 & 0.516 & -0.503 & -0.359 & -0.433 & -0.421 & -0.400 \\
\hline JRKI & & & & & 1.00 & $-0.657^{* *}$ & $-0.607^{* *}$ & $-0.627^{* *}$ & -0.502 & -0.129 \\
\hline KLORO A & & & & & & 1.00 & $0.963^{* *}$ & $0.985^{* *}$ & $0.902^{* *}$ & -0.069 \\
\hline KLORO B & & & & & & & 1.00 & $0.965^{* *}$ & $0.931^{* *}$ & -0.201 \\
\hline TTLKLORO & & & & & & & & 1.00 & $0.929^{* *}$ & -0.140 \\
\hline Carotene & & & & & & & & & 1.00 & -0.247 \\
\hline ANTO & & & & & & & & & & 1.00 \\
\hline
\end{tabular}

Description: ** very significantly correlation at level $\alpha 1 \%, \mathrm{BBT}=$ fruit weight per plant, JB = number of fruit, DMB $=$ diameter of fruit, $\mathrm{PJB}=$ length of fruit, JRKI = distance internode, Kloro A $=$ Chlorophyll- $\alpha$, Kloro $\mathrm{B}=$ Chlorophyll- $\beta$, Ttlkloro $=$ total chlorophyll, Carotene $=$ carotene, Anto $=$ anthocyanin

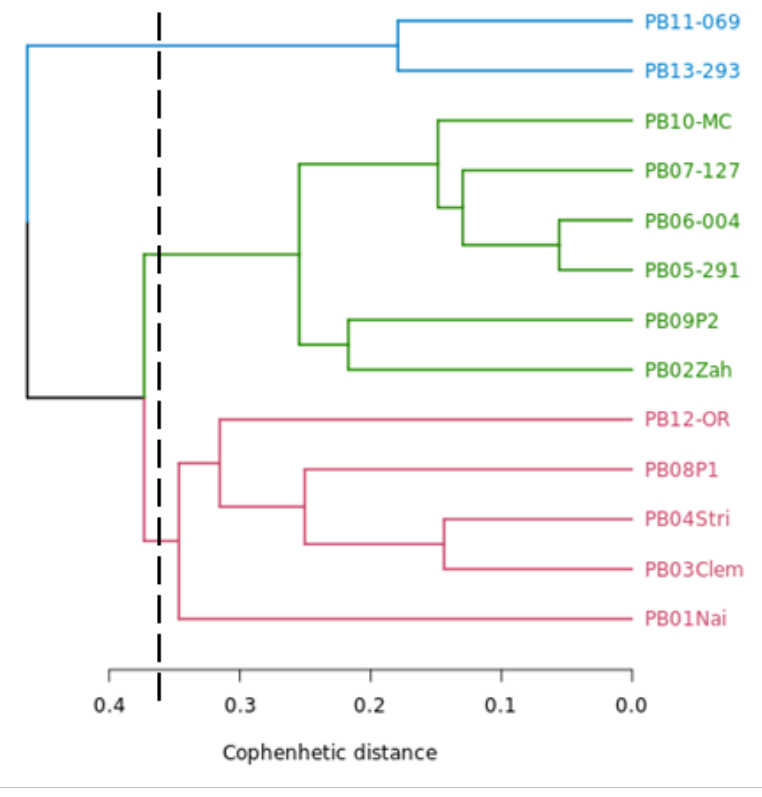

Figure 1. Dendogram 13 Genotype Okra

\section{CONCLUSION}

In conclusion, based on the results of the analysis carried out on 13 okra genotypes showed that the okra fruit which has the best carotene and chlorophyll content was genotype PB11-069. Okra fruit possessing the highest anthocyanin content was PB05-291. The cluster analysis showed that okra was clustered into three color groups. The anthocyanin content in okra fruit did not correlate with the yield component variable. chlorophyll- $\alpha$, chlorophyll- $\beta$, and total chlorophyll were positively correlated to carotene in okra fruit and variable choice of fruit. The character of number and weight per plant greatly influences the determination of the selection process. Accordingly, the characters can be used as a selection character so as to produced a high yield okra and contains chlorophyll and carotene.

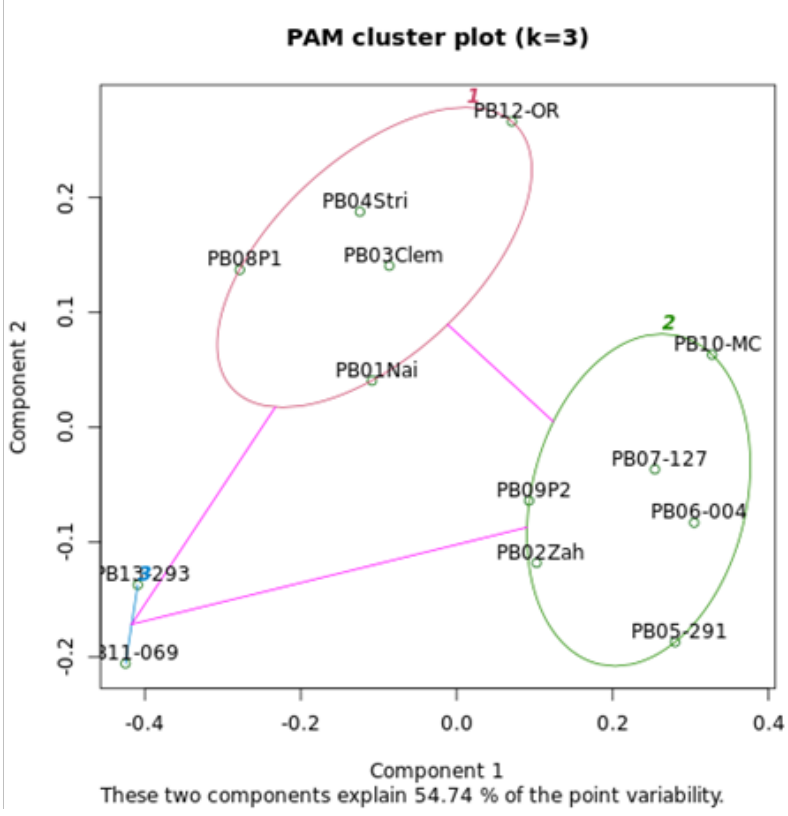

Figure 2. PAM cluster grouping plot 13 genotype okra

\section{ACKNOWLEDGMENTS}

The authors would like to acknowledge the Ministry of Research, Technology and Higher Education of the Republic of Indonesia for funding this research through the 2017-2018 National Innovation System (Insinas) Research Incentive Grant with Muhammad Syukur as the principal investigator.

\section{REFERENCES}

Alsuhaibani AM, Nora MA, Amal HA and Nora AAF. 2017. Effects of chlorophyll on body functioning and blood glucose levels. Asian J Clin Nutr 9 (2): 64-70.

Ashok P, Kumud U. 2012. Tannins ar astringent. J Pharmacognosy Phytochemistry 1 (3): 1-6. 
Barky ARE, Samy AH, Abeer AEAE, Yehia AH, and Tarek MM. 2017. Saponins and their potential role in diabetes mellitus. Review Diabetes Manag 7 (1): 148-158.

Block G. 1994. Nutrient sources of provitamin A carotenoids in the American diet. Am J Epidemiol 139 (3): 1-4.

Falconer DS, TFC Mackay.1996. Introduction to Quantitative Genetics. 4 th ed. Longman, London.

Gemede HF, N Ratta, GD Haki, AZ Woldegiorgis, F Beyene. 2015. Nutritional quality and health benefits of okra (Abelmoschus esculentus): a review. J Food Proc Technol 6 (6): 1-6.

Harbone, J.B. 1998. Phytochemical Methods. Chapman and Hall. London.

IBPGR [International Board For Plant Genetic Resources]. 1991. Report Of An International Workshop On Okra Genetic Resources: held at National Bureau for Plant Genetic Resources (NBPGR). International Board For Plant Genetic Resources, India.

Inanc AL. 2011. Chlorophyll: Structural Properties, Health Benefits and Its Occurrence in Virgin Olive Oils. Acad Food J 9 (2): 26-32.

Johnson WW, Robinson HF, Comstock RE. 1955. Genotypic andphenotypic correlations in soybeans and their implications in selection. Agron J 47: 477-482.

Khoo HE, KN Prasad, KW Kong, Yueming J, and Amin I. 2011. Carotenoids and their isomers: Color pigment in fruit and vegetables. Molecules 16: 1710-1738.

Kumar DS, Tony DE, Kumar AP, Kumar KA, Rao DBS, Nadendla R. 2013. A review on: Abelmoschus esculentus (okra). Intl Res J Pharm App Sci 3 (4): 129-132.

Kumar R, Rajasree V, Praneetha S, Rajeswari S, Tripura U. 2018. Correlation and path coefficient analysis studies in pumpkin (Cucurbita moschata Duch. Ex poir) for yield and quality traits. Intl J Curr Microbiol App Sci 7 (5): 1-9.

Kumar S, and Medagam TR. 2016. Correlation and path coefficien analysis for yiled and its components in okra (Abelmoschus esculentus (L.) Moench). Adv Agric Sci 4 (4): 72-83.

Lichtenthaler HK. 1987. Chlorophylls and carotenoids: pigments of photosynthetic biomembranes. Meth Enzymol 148: 350-382.
Marrelli M, Filomena C, Fabrizio A, and Giancarlo AS. 2016. Effect of saponins on lipid metabolism: A review of potential health benefits in the treatment of obesity. Molecules 21 (1404): 1-20.

Mazza GJ. 2007. Antocyanins and heart health. Ann Ist super sAnItà. 43 (4): 369-374

NPBGR [National Bureau for Plant Genetic Resources]. 2000. Minimal Descriptor (For Characterization and Evaluation of Agri-Horticultural Crops, Part 1. National Bureau for Plant Genetic Resources, India.

Nurcholis W, N Khumaida, M Syukur, M Bintang, IDAAC Ardyani. 2015. Phytochemical screening, antioxidant and cytotoxic activities in extracts different rhizome parts from Curcuma aeruginosa RoxB. Intl J Res Ayurveda Pharm 6: 634-637.

Prakoso LBA, Mambo C, Wowor MP. 2016. Test the effect of okra (Abelmoschus esculentus) fruit extract on blood glucose levels in wistar rats (Rattus norvegicus) induced by alloxan. e-Biomedic J 2 (4): $1-5$.

Rotblatt M, Zimet I. 2002. Evidence-based herbal medicine. Haney \& Belfus, Inc., London.

Sims DA, Gamon JA. 2002. Relationships between leaf pigment content and spectral reflectance across a wide range of species, leaf structures and developmental stages. Rem Sens Environ 81: 337-354.

Sindhu RK, Vishal P. 2016. Phytochemical, nutritional and pharmacological evidences for Abelmoschus esculentus (L.). J Phytopharmacol 5 (6): 238-241.

Sultan A, Abdul RR. 2015. Steroids: A diverse class of secondary metabolites. Med Chem 5 (7): 310-317.

UPOV [International Union for the Protection of New Varieties of Plants]. 1999. Guidelines for the conduct of distinctness, uniformity and stability: Okra (Abelmoschus esculentus (L.) Moench). International Union for the Protection of New Varieties of Plant, Geneva.

Znidarcic D, Dean B, Helena S. 2011. Carotenoid and chlorophyll composition of commonly consumed leafy vegetables in Mediterranean countries. Food Chem 129: 1164-1168. 